\title{
Adenosarcoma TNM Finding v7
}

National Cancer Institute

\section{Source}

National Cancer Institute. Adenosarcoma TNM Finding v7. NCI Thesaurus. Code C89606.

A finding about one or more characteristics of adenosarcoma, following the rules of the TNM AJCC v7 classification system. 